\title{
How Conscious is a Compulsive Buyer? A Case Study ${ }^{1}$
}

\author{
Semra DOĞAN*
}

\begin{abstract}
Compulsive buying is often studied in the field of psychiatry and marketing as a behavioral disorder. While individuals who exhibit compulsive (excessive) buying behavior hold common features in terms of some characteristics, there is limited information about the extent to which consciousness is included in the purchase decision, the awareness of the individual and the extent to which s/he can control himself / herself in purchase behavior. In this case study, I made in-depth investigations about the excessive purchase behavior of an individual whom I identified as a compulsive buyer according to a compulsive buying screener. I have developed the themes of excessive (compulsive) buying motivations and conditions, conscious consumption, buying process and buying consciousness and identified sub-themes. The findings I have obtained show that the compulsive buyer, who is a female consumer, exhibits similar characteristics with the relevant literature by excessive purchase behaviour especially in clothing and similar products. On the other hand, she also takes precautions by creating a consciousness to prevent excessive consumption during shopping process, which she sees as a leisure time activity. In other words, while making purchases with the motivation of public self-consciousness, she tries to prevent this by showing private self-consciousness. In the conclusion I related them to the relevant literature and proposed recommendations.
\end{abstract}

Keywords: Compulsive Buying, Self-Consciousness, Qualitative Research, Case Study

JEL Classification: M31

\section{Kompulsif Tüketici Ne Kadar Bilinçli? Bir Örnek Olay Çalışması}

\section{öz}

Kompulsif satın alma, genellikle psikiyatri ve pazarlama alanında bir davranış bozukluğu olarak incelenir. Kompulsif (aşırı) satın alma davranışı sergileyen bireyler bazı özellikler açısından ortak özellikler taşırken, satın alma kararında bilincin ne ölçüde yer aldığı, bireyin farkındalığı ve satın alım sürecinde kontrolü ne ölçüde sağlayabildiği konusunda sınırlı bilgi bulunmaktadır. Bu örnek olay çalışmasında, bir kompulsif satın alma eleme aracına göre kompulsif alıcı olarak tanımladığım bir bireyin aşırı satın alma davranışı hakkında derinlemesine araştırmalar yaptım. Aşırı (zorlayıcı) satın alma motivasyonları ve koşulları, bilinçli tüketim, satın alma süreci ve satın alma bilinci temalarını geliştirdim ve alt temalar belirledim. Elde ettiğim bulgular kadın tüketici olan kompulsif alıcının özellikle giyim ve benzeri ürünlerde aşırı satın alım yaparak ilgili literatürle benzer özellikler sergilediğini, öte yandan bir boş zaman aktivitesi olarak da gördügü alışveriş sürecinde aşırı tüketimin önüne geçmek için bir bilinç oluşturarak kendince önlemler de aldığını göstermektedir. Bir başka ifadeyle public self-consciousness motivasyonu ile satın alım yaparken private self-consciousness göstererek bunun önüne geçmeye çalışmaktadır. Sonuç bölümünde bunları ilgili literatürle ilişkilendirdim ve önerilerde bulundum.

Anahtar Kelimeler: Kompulsif Satın Alım, Öz-Bilinç, Nitel Araştırma, Örnek Olay

JEL Sinıflandırması: M31

Geliş Tarihi / Received: 31.07.2021 Kabul Tarihi / Accepted: 26.08.2021 Doi: 10.17541/optimum.976890

\footnotetext{
${ }^{1}$ This study was presented as an abstract at the 25th Marketing Congress held online (30 June-2 July 2021).

* Dr. Öğr. Üyesi, Kütahya Dumlupınar Üniversitesi, İ̈BF, İşletme Bölümü, semra.dogan@ dpu.edu.tr, ORCID: 00000002-6466-8734
} 


\section{INTRODUCTION}

It was revealed in the 1950s that consumers (individuals) do not only exhibit a utilitarian consumption behavior, but also consider social and psychological factors during exchange behaviour (Levy, 1959). Today, consumer behavior is mostly interpreted in the consumption culture, and individuals do not only exhibit a consumption behavior to meet their basic needs like eating, drinking, dressing etc. but they also make purchases without thinking deeply and with a real need to purchase goods or services. Such purchase behavior is mostly impulsive, the reasons behind them are not interpreted as rational and people are not even aware of it. Consumer culture in which consumers desire and consume goods and services that are valued for non-rational reasons such as status (power), pursuit of pleasure and excitement, and furthermore provocation (Belk, 1988).

Faber and O'Guinn (1992) emphasized the necessity of studying only the "good" and functional aspects of consumer behavior, arguing that it is incomplete and moreover negligent, and that it is necessary to study its negative aspects. Especially in consumption culture where shopping has become a socially acceptable addiction, compulsive purchasing behavior can also be examined among typical consumption disorders representing the dark side of consumption together with store theft, alcohol, and drug addiction (Faber et al., 1995).

Compulsive buying has received widespread attention in psychiatry and psychology, along with marketing (Winestine, 1985; Krueger, 1988; O'Guinn and Faber, 1989; Scherhorn et al., 1990; Ridgway et al., 2008; Kearney and Stevens, 2012; Granero et al., 2016). Though the underlying causes of this behavioral disorder have often been investigated, much is not known whether the consumer behaves conscioussly, to what extent they control themselves in their buying behaviour. Public consciousness is found to be related to compulsive buying (Xu, 2008). However, it is not clear whether this motivation is distinguished from conspicuous consumption, and they also disregard inner self and self-recrimination. In this study, the purchase behavior of an individual exhibiting compulsive buying behavior has been examined closely in terms of these characteristics and relevant findings are presented. To do this, first conceptual framework and relevant literature findings are presented. Then the research process including participant selection, data collection and analysis and the themes developed under findings are put forward. The research concludes with theoretical discussions and recommendations with reference to the relevant literature.

\section{COMPULSIVE BUYING AND SELF CONSCIOUSNESS}

\subsection{Compulsive Buying}

Compulsive buying is not a new concept, it was first conceptualized as 'oniomania' in 1915 by Emil Kraepelin, who is seen as the father of modern psychiatry, and expressed the concept as an unstoppable drive towards purchasing (Black, 2007; Kearney \& Stevens, 2012; Bighiu et al., 2015). An important work on this subject came from Eugen Bleuler. However, Bleuler, discussing oniomania with hysteria attributed to women, with a sexist interpretation, emphasized that oniomania always includes women as a permanent debt-maker with their motives and constant pursuit of pleasure (Kearney and Stevens, 2012: 234).

Today, this behavioral disorder, which is more encouraged by the increase of stimuli especially with the developments in internet technologies, has started to be studied more frequently in the fields of psychiatry. Compulsive Buying Behavior (CBB), also known as shopping addiction, pathological purchasing, or compulsive purchasing disorder, is characterized by the purchase of continuous, excessive, impulsive and uncontrollable products despite serious psychological, social, professional, financial consequences and defined as a mental health 
condition (Müller et al., 2015). Although compulsive buying behavior can be used interchangeably with concepts such as shopping addiction and compulsive spending (Dittmar et al., 1996), shopping addiction is a milder version of compulsive buying disorder in terms of effective treatment and intervention methods, and shopping addicts are aware of this addiction and avoid shopping. Consumers with compulsive purchasing disorder, on the other hand, deny it while they cannot hold back (Bas, 2016).

Compulsive buying disorder has also been the subject of research in terms of its antecedents and consequences. Consumers with compulsive buying disorder may turn to excessive purchasing in order to get out of their negative mood (Ridgway et al., 2008), and this tendency can become the primary response to negative events and moods and turn into chronic, repetitive excessive buying behavior (Lejoyeux \& Weinstein, 2010). The non-addicted ordinary consumers focus on the value and functionality of the products as the main motivation factor in their purchases, while compulsive consumers exhibit purchasing behavior with motivations such as improving negative moods such as sadness, loneliness, anger, coping with stress, social acceptance / recognition, and self-image (Lejoyeux vd., 1996; Desarbo and Edwards, 1996; Vogt et al., 2014; Roberts et al., 2014; Granero et al., 2016).

Compulsive purchasing disorder can be justified by family environment, socio-cultural environment, commercial environment, and advertising activities as well as genetic factors, while financial constraints may direct the individual to other extreme consumption modes by preventing excessive purchasing behavior (Valence, 1988). Although its etiology (causes / origins) can be explained by genetic, social, and personal theories, it is also considered as a behavior that is learned independently from these (Hirschman, 1992).

Compulsive buying behavior does not improve the quality of life in the long term but leads to financial negative consequences such as the increase in the debt burden of the individual and the difficulty in paying these, financial legal consequences (d'Astous 1990; Ridgway et al., 2008; Joireman et al., 2010), it can bring psychiatric disorders such as depression and even social negativities (Pirog and Roberts, 2007; Konkoly et al., 2015). As a matter of fact, while the individual experiences a short-term emotional rise after the purchase, s/he immediately experiences remorse and regret (Chaker, 2003; Faber and O'Guinn, 1992).

\subsection{Self-Consciousness}

Self-consciousness is defined as directing the individual's attention to himself / herself (Fenigstein et al., 1975: 522) and a tendency to direct attention to inside or outside of oneself (López-Bonilla et al., 2018). Self-Consciousness Scale developed by Fenigstein et al. (1975) stated that there are three aspects of self-consciousness to evaluate individual differences in selfconsciousness: namely Private Self-Consciousness, Public Self-Consciousness, and Social Anxiety. The first two aspects measure a person's psychological tendencies that focus on $\mathrm{him} /$ herself. Private self-consciousness is concerned with the tendency to be introverted about one's thoughts and feelings. Public self-consciousness refers to looking at yourself as a social object in relation to how others see the self and the impression it creates on others. Social anxiety refers to the discomfort caused by being in the same place with other people. Private self-consciousness includes hidden, personal, unshared aspects of the self that cannot be observed by others (e.g., attitudes, emotional states) (Scheier, 1980), while the public selfconscious state is an individual's physical appearance, fashion or purchase behavior that is publicly visible (Solomon \& Schopler, 1982; Kwon, 1992; Marquis \& Filiatrault, 2000). Social anxiety is defined as the disturbance caused by the presence of others (Fenigstein et al., 1975: 523), and it can be thought to stem from public self-consciousness, as the individual's subjective experience requires focusing on the external self (Scheier \& Carver, 1985). In other words, while 
public and private self-consciousness is the process of focusing on the self, social anxiety refers to the reaction to this process.

\subsection{Literature Review}

Consumers with compulsive buying disorder are individuals with low self-esteem and tendency to negative moods such as depression, anxiety, obsession, and stress (O'Guinn ve Faber 1989; d'Astous vd., 1990; Dittmar ve Drury 2000; Ridgway vd., 2008). Considering compulsive buying as a quick solution to anxiety (Valence et al., 1988), the main motivation of such consumers is to try to reach their goals of acceptance by their social circles and realizing their self-esteem rather than a strong desire to possess something (O'Guinn and Faber. 1989). Moreover, while these individuals exhibit more materialistic, more jealous, less generous personality traits; they are more interested in the entertainment and fantasy aspects of consumption (d'Astous et al., 1990; Park \& Burns, 2005; Dittmar, 2005; Mueller et al., 2011; Claes et al., 2016). Due to their low self-esteem and desire to feel better, compulsive buyers are expected to need more information about the latest fashion trends, while these consumers may prefer to purchase more and more expensive (Park \& Burns, 2005; Kukar Kinney, 2009; Raab, 2011). In an effort to improve their public image, it has been observed that individuals with high public self-consciousness prefer nationally branded products to low-priced branded products (Bushman, 1993). However, the presence of the internet retail environment encourages compulsive buying as it allows avoiding direct, face-to-face social contact, allows confidentiality of shopping (for example, hidden from family) and provides continuous electronic feedback on product offerings and prices (Lejoyeux and Weinstein, 2010: 2).

On the other hand, there are discrepant findings regarding whether there is a genderbased difference in compulsive buying behavior. While studies in the United Kingdom and Germany do not indicate a significant difference between males and females in terms of compulsive buying (Koran et al., 2006; Müller et al., 2010), studies conducted on university students indicate significantly higher rates of female students buying compulsively (Claes et al., 2011; Harvanko et al., 2013). Gender-related behavioral difference is also seen in the products purchased where women mostly buy cosmetics and clothing products; men, on the other hand, exhibit compulsive buying behavior in electronics, automotive and hardware products (Black, 2007).

Following the relevant literature, I draw above; I designed the research by reference to the following questions:

1. Why does compulsive/excessive buying occur? What motivations are there for the individual to compulsive buying?

2. When / under what conditions does an individual interpret her purchasing behavior as excessive?

3. To what extent the individual behaves aware when making purchases?

4. How does the individual define conscious consumption? What is her perception about her exhibiting a conscious consumption behavior? To what extent does she think she makes the decision consciously in the purchasing process? What kinds of internal and / or external factors is it(purchase) affected by? 


\section{METHOD}

In this study, the case study design, one of the qualitative research methods, was adopted. Creswell (2009) defined the case study as "a research strategy in which the researcher investigates a program, event, activity, process or one or more people in depth" (Creswell, 2009: 13). When asking how and why questions about an issue, case studies are suitable for seeking answer for such issues (Yin, 2003; Baskarada, 2014) obtaining a holistic view in relation the relevant research problem (Baxter and Jack 2008). In that way, case study research is capable of testing theories by refining and/or refuting as well as building theories, and thus providing the existing knowledge with new insights (Vissak, 2010)

There are also various critiques regarding the case studies, especially that the single case study cannot be generalized (Flyvbjerg, 2006; Vissak, 2010; Baskarada, 2014). However, Tellis (1997) and Yin (2003) previously indicated that the generalizations of case study results are made to theory not to populations (by analytical generalisation) and it is possible to do it on a single case. The unit of analysis, in a way the case might also be either an event, a process, an individual, a group, or an organisation (Yin, 2009). To collect data of this depth and richness, I considered the single case study option to work on a compulsive consumer with accessible closeness and distance. Therefore, the single case study method has been adopted with a participant suitable for the research. Overall, this study examines the shopping experience of an individual (as the unit of analysis) with compulsive buying feature for two months.

\subsection{The Researcher}

I, Dr. Dogan, have been working as a lecturer in marketing for ten years. While my primary field of study is consumer behavior, I also do research on marketing communications and marketing research. It is my special interest to do unique research on consumer behavior, based on my own experiences, I have a special interest in compulsive buying and have been reading about it for a long time. Such consumers have been attracting my attention for a long time, as I have friends around me who also exhibit excessive consumption behavior. While many studies have been carried out on compulsive buying in different fields including marketing, I wanted to closely examine a typical compulsive buyer and closely monitor this behavioral pattern with a case study.

\subsection{The Site of the Study}

The site of the study is a tiny town that is located in the inner western part of Turkey. In this city there is only one shopping mall but many little stores in the city center. People usually go to another city that is an hour away from the city. In this greater city, there are two larger shopping malls and stores.

\subsection{Participant Selection}

Belk (1973) previously found out that gift giving behaviour rises during special occasions like birthdays, Christmas. The sales promotions also make consumers purchase more than they expect (Vitor et al., 2013) and sellers adopt such promotions during special occasions. For this study, a compulsive buyer was the case as compulsive buying is a significant issue both in consumer behaviour and psychiatry and it is not clear whether compulsive buying is a disease or just a temporary buying disorder. Therefore, it is expected that this case would contribute to the field by delving into a compulsive buyer's 2-month-buying behaviour from the beginning of 
November and the end of December 2020 during which a discount period including Black Friday and Christmas was experienced.

When choosing the participant, I first shared a compulsive buyer screening questionnaire on my social media account, Whatsapp (see the appendices). I preferred my private account made up of my friend since this is a delicate subject and anyone might avoid sharing their info or experience. I received responses in a while and decided on the one getting the highest score (with the most 'Yes' (7) answer). The participant I selected according to the relevant criteria was a friend of mine. She is a working woman at her 30's, married, born and raised in the site of the study. During the study I will mention the participant with a pseudonym (April).

\subsection{The Data Sources \& The Collected Data}

Case study is a type of qualitative research that allows the use of more than one data collection technique. In this respect, it increases the reliability of the research and can provide cross-check while confirming the findings (Yin, 2003). The data sources in question can be interview, observation (direct and participant), documents, physical works (Yin, 2003; Stake, 1995). In this study, data sources such as interviews, direct observation, receipt, invoice, etc. regarding the shopping history, and images of purchased products were used to contribute to the understanding and examination of the research subject.

I conducted the interviews face-to-face with a semi-structured interview form, and in the unstructured interviews by phone and message application. Creswell (2009) states that face-toface questionnaires as well as telephone and e-mail interviews are also accepted. In this regard, I made the main meeting face to face. In line with April's request, I also made interviews by phone about her shopping experiences during two sales promotions of Black Friday and the New Year.

I made my observations by going with her while she was shopping, upon April's approval. During the shopping, I had the opportunity to closely examine her behavior, decisionmaking process, products she bought, and her interaction with sales representatives.

As documentary evidence, I examined photos from April's house, wardrobe, etc., and shopping receipts. In this way, I examined the variety of products purchased and the frequency of purchases. Considering her privacy concerns, at her request, I only used the images for data analysis.

I obtained her written consent for all the data I would collect and informed her that both information (visual and oral) and identity would remain confidential. Ethics committee approval required for the study are also obtained.

\subsubsection{The Interviews}

In this study, in addition to contributing to validity and reliability by providing data diversity (Merriam, 1998; Stake, 1995), I interviewed the participant because it provided the thick description, which is an important criterion in validity. Another reason for collecting interview data in this study was the fact that the interviews are an important data collection technique in qualitative research as they allow the individual to express the world of meaning himself and present data that we cannot reveal with other data collection techniques (Patton, 1987).

I conducted a face-to-face interview with a semi-structured interview form. I made the face-to-face interview at the beginning of the study (at the beginning of November) in order to provide more comprehensive information about the participant and to see the current course of shopping in her usual life practice. The face-to-face interview lasted about an hour. In this interview, I told the participant the purpose of the research, the importance of the information I 
will obtain from her for the research, that she can terminate the interview at any time, she can give the answer she wants during the interview, and also ask her own questions.

With the probable emergence of the desire to shop, I made phone calls during the research period (one in Black Friday and the other in December) in order to understand what motivations, she wants to shop with, what she wants to shop for etc. In both interviews, I also made post-shopping interviews in order to understand the feelings and thoughts after the purchase. I preferred the unstructured interview format for these four interviews, which lasted an average of 15 minutes. In addition to the phone calls, she also messaged to me when she felt online shopping desire. I tried to reveal the products she was considering to buy and why she wanted to buy them. Transcription of the interview data started immediately at the end of the interviews and when completed, it was sent to the participant to check the accuracy of the interview transcript, ensuring validity.

\subsubsection{Direct Observations}

Observation is one of the most used data collection techniques in qualitative research. Bailey (1982) stated that a researcher who wants to examine a behavior in any environment in detail and comprehensively can use the observation technique and added that structured or unstructured observations can be made within this scope. As part of this research, I went shopping with April and collected my observation data by observing her experiences directly while shopping with her.

I collected data with unstructured observation technique on the stores she chose during shopping, her behaviour in the store, the duration of her stay in the store, whether she bought it or not, and her interaction with the store employees. I also observed her wardrobe and various other products at her home.

\subsubsection{Documentary Evidence}

Interviews were the primary data in this study. I also benefited from the documents in this study to make the statements of the participant explanatory and to confirm it in a way. Documents are sources that provide data to the researcher without observation or interview. In this respect, documents that save time and money can be in the form of memories, diaries, photographs, personal documents, and documents (Bailey, 1982). The document review contributed to the validity and reliability of the research, both as a triangulation and a thick description. The documents I have examined in this research are as follows: the shopping receipts during the research process, photographs from the participant's house and from various places (wardrobe, hall alike) in her home.

\subsection{Data Analysis}

In this study I analyzed the data following Strauss and Gorbin's (1998) grounded theory procedure. Denzin and Lincoln (2005, p.508) indicates that grounded theory "consists of simultaneous data collection and analysis, with each informing and focusing the other throughout the research process". Doing constant comparative analysis, I related data collection and data analysis as the method requires. As Morse and McEvoy (2014) also applied in their study in the field of sport finance, I reviewed, evaluated, and organized interview transcripts, observations and documentary evidence including shopping receipts, purchase orders, store subscriptions, mobile applications of the stores she keeps on her mobile phone. Following the coding procedures of grounded theory by Strauss and Corbin (1998), I first analyzed each interview (face to face and phone call interviews) with the constant comparative analysis, identified categories after the open coding phase. Utilizing axial coding, I related each interview and other forms of data to collect them under certain categories. In the phase of selective coding, 
I identified the core categories and linked different categories to the core categories (Strauss and Corbin, 1998). The core categories I identified are: motivations to excessive (compulsive) buying behaviour, excessive (compulsive) buying conditions, conscious consumption and buying process and buying consciousness. Based on concepts and categories I, then, developed themes. During category identification and theme development, two colleagues of mine who are also expert in the field collaborated with me.

\subsection{Qualitative Internal Validity and Qualitative Reliability (Dependability)}

I tried to provide a set of criteria to ensure validity and reliability in the data I collected. Creswell (2009: 162) stated the factors that threaten the internal validity as the factors that arise from the procedures followed in the research process, the functioning or the experiences of the participants and prevent the researcher from making inferences about the population under study. In this case study, I provided triangulation, member checking, thick description and internal validity in order to eliminate these types of factors threatening internal validity.

Triangulation is defined as using more than one researcher, more than one data source or more than one method to verify the findings (Merriam, 1998: 204). Triangulation thus provides the opportunity to review our inferences. Utilizing data triangulation, I collected data by inteviews, observations and documentations.

With member checking, I sent back the data and my temporary comments on this data to the participant, and I received a kind of confirmation (Merriam, 1998: 204). In this way, the threat of misinterpreting the data originating from the researcher is eliminated. So, I sent my interview data to April to confirm that I transcribed the recording correctly and asked her to check it.

As a Personal Statement, my own experience of compulsive buying and how conscious it is done and what kind of intrinsic-extrinsic motivations feed on have been an important motivation to investigate this issue. As I am a person who likes shopping, even excessively, I wondered about the motivations of my friends who displayed similar buying behavior while thinking about my own experiences. Do we show similarities? Where do we separate?

Thick Description is making a rich description of the case study and its participants allows the readers to understand the environment vividly and to match the research situation with their own conditions, in a way, to transfer between the conditions in the case study and their own experience (Creswell, 2009). In this study, I tried to make a wide definition and description of the compulsive buyer and her experiences, both with the interviews and the documents she shared.

Qualitative reliability is defined by Creswell (2009) as consistency between different researchers and projects. Merriam (1998) and Yin (2003) indicate that qualitative reliability is finding the same results when repeating the study. In this study, the position of the researcher and the audit trail were provided with triangulation, which is also an important factor in validity to ensure reliability.

As Investigator Position, the researcher's assumptions, theoretical background, sampling method, details about the participants and the environment they are studied are important elements in ensuring reliability in qualitative research. I have presented a conceptual framework and literature review on compulsive buying and self-consciousness issues and their relationship, along with my own experience of the research topic. During the research process, I stated in what ways I interviewed the participant, how I collected observation data, and what my document data sources were. 
An Audit Trail is the part of qualitative research in which details about the data collection process, methods used and how the data are analyzed. Field notes, expressed as a written explanation of the observation on the audit trail, include a breakdown of the interviews (Miles and Huberman, 1994). The audit trail for this study is presented in the appendix at the end of the text.

\section{FINDINGS}

The purpose of this study is to identify the motivations that makes compulsive buyer purchase, what and how often and why and how she buys; to reveal the consciousness and the extent to which out of control she acts during her purchases. Following the data analysis, I developed the themes and relevant categories below.

\section{Theme One: Excessive (compulsive) buying motivations}

April said shopping was often a leisure activity for her, and sometimes it was a kind of comforting to compensate for her demoralization. She said she did noticeably more shopping, especially if the sale periods coincided with demoralization.

Sometimes I just can't find anything to do. There are times when I don't want to meet with my friends. Especially in the pandemic, we cannot meet much outside, although we already want it. I go to the mall a lot out of boredom. I do this a lot under normal conditions. I guess going and shopping is one of my favorite things in my spare time. Of course, I'm not just going around (smiley) I want to buy things that I like as I see. Maybe I have never returned emptyhanded from my shopping mall tour (smiley) I wouldn't go around just to see what's going on, so it happens very often that I just can't stand buying the things that I like.

From this statement of April, I noticed that she sees shopping primarily as a leisure activity. I saw that she went shopping when he could not find anything other to do because she also let me know when she wanted to shop. On the other hand, it is an important detail for me that she does not spend shopping mall visits without purchases. I also experienced that she did not complete the shopping mall visits without making a purchase. Saying that mood is also an important factor in shopping, April stated that she is more inclined to shop when she feels unwell.

I have not stopped since I realized that shopping is the most comforting thing for me when I am upset and depressed (smiley). Considering my fondness for clothing products, I can say that buying new things and seeing them on me is very effective in getting me out of bad mood.

When I look at her statements about how sales promotions such as discounts affect her, I can say that there is another shopping stimulus for April. The times she wanted to shop during the research process coincided with the discount period. She shared the notifications of her favorite brands with me via cell phone message.

... Price cuts... of course I'm affected. I also make sure that it is discounted while I'm shopping. I buy a lot of clothes, yes but I don't buy almost any of them from the season. The discounted price, as you know, stimulates me, even if I do not need it, I ask myself how to miss it, it has fallen at such an affordable price. Think about it, a sweater with a season price of 500 Liras has fallen to 150 Liras. At that moment, I focus not on whether I need that sweater or not, but on how much discounted price I buy that sweater.

I saw that April was picky in terms of brand in the products she bought while shopping. Stating that she prefers branded products, April said that she did not miss the discount periods of these products. When I examined the shopping vouchers April shared with me, I had findings 
that confirm this; her frequent purchases of high sums were on premium branded clothing products.

I do my shopping, especially the unnecessary and excessive part, for clothing. I prefer branded, high-priced products in clothing. Wearing that brand gives me an incredible pleasure. Especially if I think that I bought it at an affordable price, my joy will increase. Visiting the brand's store is also enjoyable and wearing it also. So, I can also say that the thing that drives me to buy too much is my fondness for branded clothing. You know, especially premium brands are already making seasonal designs. I also love to buy and wear those models on sale. For example, it is not important for me to wear the autumn-winter season products of three years ago, it is enough for me to buy that brand at an affordable price according to its own average. That's why I often visit the outlet stores of those brands. Even if I buy it from the website, I often check the outlet aisle.

Another important thing April said was that someone making purchases in her social circle was driving her to buy. In this respect, I saw that she was going for a social comparison. In one of our whatsapp messaging, she mentioned a friend of hers buying a watch and she immediately started to search for watches.

Sometimes I tell myself, okay I won't buy anymore. It happens that I don't buy for a long time (of course, long for me-smiley-). Then I hear that a friend of mine has bought something very expensive, his/her purchase of that product opens space for me and gives me the right to buy something new for myself. I am almost saying that I should not stay behind him/her. I am immediately buying something for myself.

April explained another reason of her excessive spending as she likes to make others happy. In other words, she stated that she could exaggerate her spending in an altruistic manner.

I love to buy gifts. Often, the gifts I buy for my loved ones are things that I will not buy for myself because of their prices. I do not avoid expense to make my loved ones happy. For example, I don't buy cheap gifts. This pushes me to buy expensive gifts. But when I buy gifts, I think about how happy the other person will be, and I immediately buy whatever gift I will buy. For example, even if my credit card is full, I will buy whatever I want.

I also saw in her statements that April was concerned about how she was perceived by others. Therefore, in her excessive buying behavior, external as well as internal; possibly more external factors are distinctive.

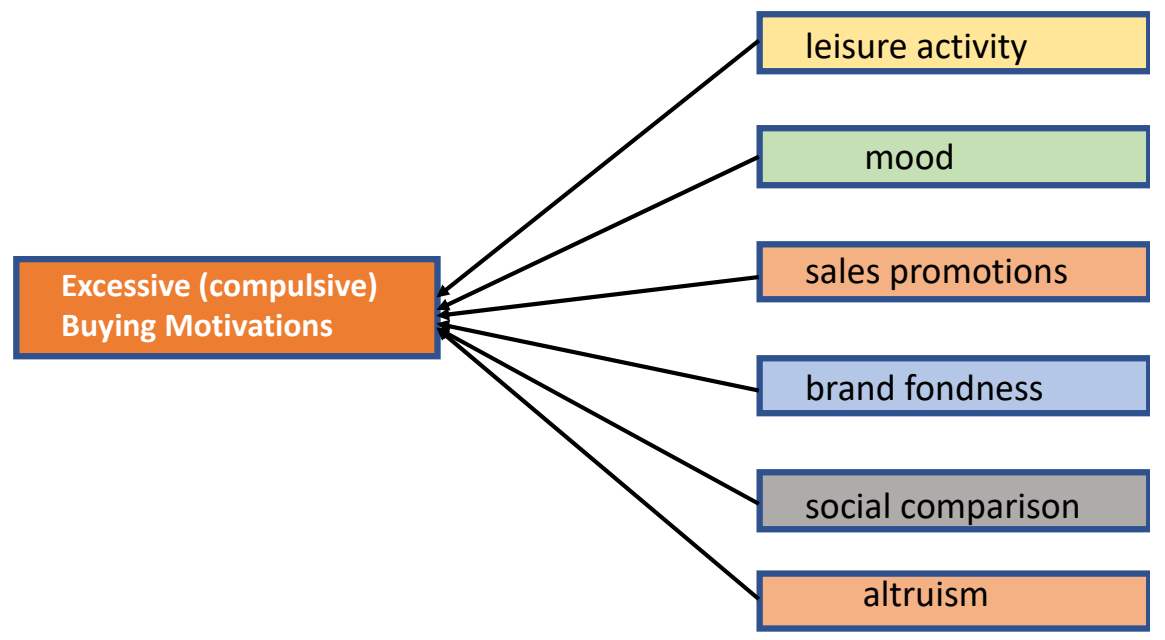

Figure 1: Theme One and Related Sub-themes 


\section{Theme Two: Excessive (compulsive) buying conditions}

April's own assessment of how extreme her purchasing behavior is, and her comments on under what circumstances she finds her purchases excessive can be interpreted as she has an awareness of this issue:

The things I buy because I really need it are obvious, household supplies. Bed, wardrobe, carpet, etc. but when it comes to clothing, I can't say that much. Apart from the dresses I bought for special occasions such as weddings, etc., I have not bought any clothes because I really needed them. If I find it cheap, stylish, and branded, I just can't stand it. I don't really look if I have the same color and same model. That's why I can say that almost all my shopping for clothing is excessive.

When I consider it as clothing and other products, it is possible to say that April's perception of over-purchasing is very strong in clothing, thus exhibiting an excessive purchase behavior that varies according to the product. However, I can say that the criticisms from her social circle about purchasing behavior also strengthen this perception.

Before I got married, I would not want my shopping order sent to home, I used to forward it to my work so that my mother would not see it and be very angry. After I got married, I started to send some to my own home and some to my family's house. So, I was cutting the risk of getting angry in half (smiley).

Once I did a lot of cosmetics shopping. I gave my working address for the delivery. An employee at work picked up my package. I was very annoyed that the invoice appeared on the box. I felt nervous thinking that if the man saw the amount of my shopping and said, what this woman did, and furthermore it made me uneasy.

... I realize how much, even unnecessary shopping, I do while I am allocating summer and winter clothes. I see, I have clothes that I have never worn and even forgotten. For example, I buy at least two colors of the same model sweater and shoes. I make combinations in my mind; I tell myself that I will definitely need this color and I buy the colors of the model that I can get.

When I saw April's wardrobe, shoes, and bags, I saw products that confirm what she said. She also explained the times she lost control over her spending on her credit card receipts. She also stated that she felt bad when she saw that her shopping vouchers reached very high amounts and that she was putting herself in financial difficulties, and moreover, she regrets it. She said that one of the moments when she felt most regretful and bad was when she barely wore the branded products she bought just because she bought it at a lower price than the normal price.

... Nice when buying... nice when I feel good... but I feel very stuck when my credit card receipts is too high. I wish I had patience; I wouldn't have bought it. Is it worth it? What is worse is that I almost never wear what I bought, I feel very upset. I feel incredibly idle when I pay so much for things I will not use. For example, I have fixed payments. I have no space for credit card. I also do not want to use, indeed. However, I preferred to pay contactless payment due to the pandemic for the last year and therefore I turned to the card.

The credit card receipts April shared with me also confirmed what she said. A few of receipts were also high.

... Actually, I think sometimes. I say how many families can make a living with the money I give to my clothes or cosmetics. I do help those kinds of people indeed. I'm trying to hold back. In fact, I haven't used a credit card for the last 1.5 years. I was angry with the bank. I was getting everything in cash. This was a good control mechanism for me. But I started to use credit card again because it provides convenience in online shopping, during pandemic especially. 
When I examine all of April's statements, it is possible to say that the motivations that push to buy and the motivations that lead to regret and judgment after the purchase are both strongly caused by external factors.

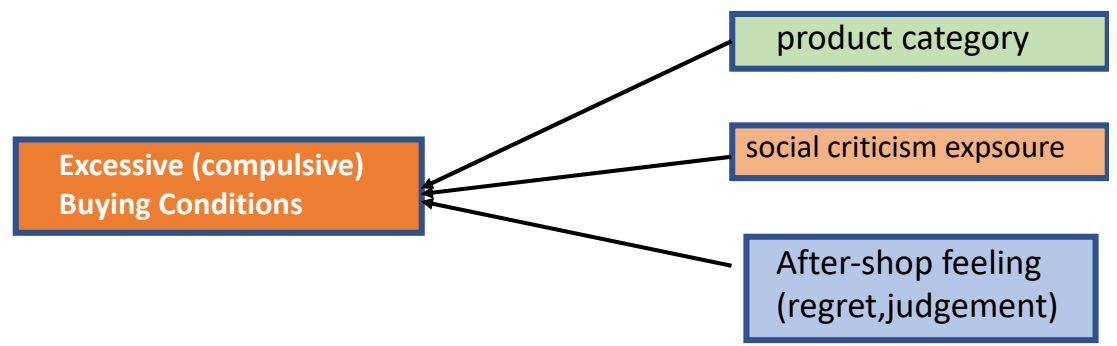

Figure 2: Theme Two and Related Sub-themes

\section{Theme Three: Conscious Consumption and Buying Process}

April said that she made unplanned purchasing decisions, which she interpreted as excessive, resulting in mostly unnecessary product purchases.

As I said before, shopping is mostly a leisure activity for me. What is wrong with this activity is that I want to buy everything I like (smiley) for example, I go to my favorite stores, and I even disregard the price if I like the product. If there is a discount, then it is inevitable for me to buy something (smiley).

April added that there were moments when she tried to be careful with this routine.

Sometimes I try to hold back. If I like a few things I try to get the one I liked the most. Or take a tour and then decide whether to buy it or not. If I have chosen this route, I often leave without taking it. Or I'm running the famous 10 -second rule, picking up the product and asking myself if I really need it. Or I calculate the upcoming amount on my credit card, and I give up.

She also stated that, with the need for social approval, when purchasing a product, April turned to the thoughts of her friends or the people she trusted in the product she was considering buying.

Another precaution that I take myself so that I don't buy anything else I don't need is to share with my friends, who I trust in the idea of what I will take and who I believe will often discourage me from shopping. Whatever it is to buy, I send the picture of it to my friends; mostly they say it is not beautiful, so I shouldn't buy it I guess (smiley) as a result, I leave without taking it, it makes me feel very good. For me, going to the mall and going out without buying anything is a great sign of success.

She said that the sales promotions practices such as lottery and quantity, price discount applied in shopping malls and stores often pushed her to unnecessary purchases. While shopping together, I observed that April could not remain indifferent to the salesperson's offers, such as a $10 \%$ discount on the second product.

I sometimes participate in the New Year's lottery in shopping malls. The salesperson informs me of the lottery, if I win a right to lottery, I'll shop a little more to win the second by his advice. I am also very fooled by the 4 buy 3 pay offers of the stores; it attracts me very much. For example, I would buy four instead of buying one and leaving the store, for example.

Another important observation of mine about April was her interaction with sales representatives during shopping. While visiting the store, I observed that April was interested in 
the products that the sales representative suggested to her, and that she definitely bought something from the store where she stayed for a long time.

... I also have a habit of feeling embarrassed towards the store staff. While visiting the store, especially if the sales representative understands that I am an easy bite, s/he never misses this opportunity, I feel like I must buy something if s/he is interested in me.

From April's statements, I once again saw that external (in a sense, social, such as salesperson) factors are a determining factor in her unnecessary purchases.

Saying that online shopping is an alternative shopping medium for her, especially during the pandemic period, April said that online shopping sites substitute physical stores in many ways. In our correspondence during the research process, I witnessed that she entered mobile applications in her spare time, looked at the products she liked over and over and finally couldn't stand it and bought it.

Just like I visit stores to spend leisure time, before I go to sleep or when I wake up in the morning, while drinking tea, I like to look at the applications of e-commerce sites or the applications of my favorite stores. For example, when I try to reduce shopping, I uninstall these applications. Notifications are already turned off. I add the products I like while browsing the applications to my favorites. But I don't buy it right away. But if it's time of sale, if there is a possibility that the product is running out, or if someone else has the possibility to buy it from my cart, I act fast. If I like it, if the price is affordable, I will quickly buy everything I like. I do not shop online very often because it is such stressful.

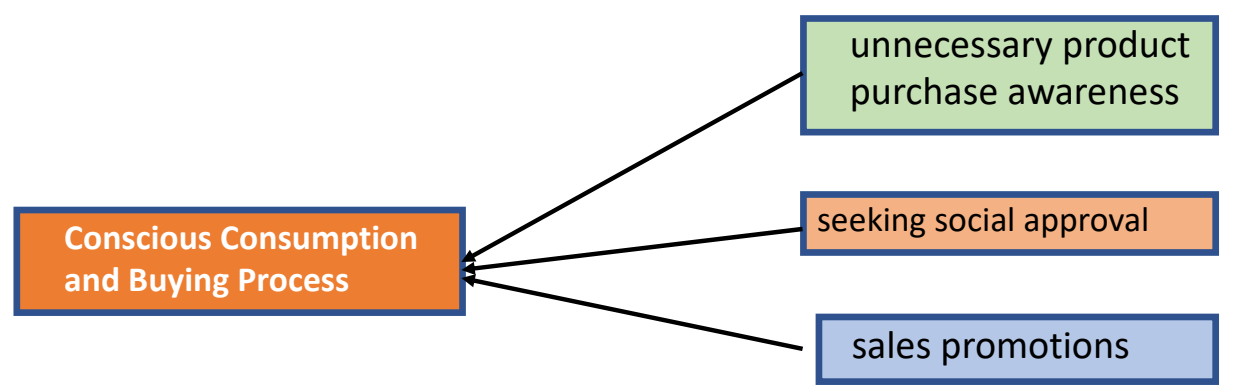

Figure 3: Theme Three and Related Sub-themes

\section{Theme Four: Buying Consciousness}

I asked April how she defines conscious consumption and whether she ever makes conscious consumption. She is aware of conscious consumption. However, she sometimes cannot stand her strong buying desire.

Conscious consumption is buying what you really need at a reasonable price, I would define. Do I make conscious consumption? I sometimes do. I already told you this. Household goods, food etc. anything other than clothing, sometimes cosmetics also, is essential and also conscious consumption related purchase, I suppose.

... Even entering a luxury store and buying something from there is a pleasure. I like it when the store employees know me after a while and know my preferences. For example, there is an incredibly expensive brand that I like very much in clothing. But it has such style products that it says, for example, I am a product of that brand. I like it when people identify me with that brand.

... There is no outlet store in the city where I live. I visit the outlet stores as I go to other metropolitan cities. I went again last week; I bought a boot that I normally say I wouldn't buy in other brands because it is very expensive but this brand I got out. Normally it was 1300 lira, 
with a 50\% discount I bought it for 650 liras. The sales representatives also said that if you buy another product with it, total amount will drop 10\% more. I bought another bag even though I never needed it. My bag hanger at home will fall to the ground, it can no longer bear the weight. But it was a discount, and I bought another bag because it shows its style. I bought a few more clothing items and paid less in total, and it satisfied me (smiley) but the following week my credit card receipt arrived. I still didn't regret it. Because the things I bought are very good. And I bought it very cheaply.

When I looked through April's comments, I saw that she spent a large amount of money on social visibility and image. So much so that even her scent preference was in this direction. I saw that April shopped with a consciousness in which external factors such as social acceptance, image and visibility are distinctive factors, and in a way, she associates this with luxury consumption. In addition to the shopping vouchers, she shared with me, I saw that the stores we visited were the stores of premium brands.

.... There is one more thing I noticed on myself: for example, my home clothes are not that important. What I wear outside should be brand, luxury brand. I officially saw me shopping with this point of view. For example, I have no such concern when buying food, furniture, etc. But even if I am going to a restaurant, I prefer luxury again. Being able to eat there also gives me pleasure. For example, I do not eat in such ordinary places. I don't know if it's called luxury addiction (smiley), I cannot give up my expensive pleasures. I guess there was such a passion.

I saw another external attribution of April's passion for shopping as her changing socioeconomic status. She told her fondness for luxury and admiration increased as her income raised, and she could finally purchase anything she used to wish at her early ages. In a way she was referring externally again.

... I had noticed an excess in my shopping frequency and amount when I first started work. As my income increased, my fondness for luxury increased. I found myself buying things that I wanted to buy but couldn't get in my adolescence. Over time, this ambitious shopping has declined, but I still make my choices for brands that I could not buy because they were expensive in my adolescence. This usually happens to people, I suppose. I mean, I'm probably not the only one who shops with that desire. But to the extent I can bear it, of course. This is a tradeoff I think (smiley).

April's comment on whether excessive buying habits might be related to disease or not was also important.

...... I don't think this is a disease. The irresistible request. It's up to me to buy something or not. If I do not go to the shopping mall, if I do not look at the websites on the internet, if I turn off the notifications, I can manage not to shop under my own control. I also know when I want to buy something, at times I can find ways to hold back. As a result, I see excessive shopping as something that I would not do if I wanted to or not, and even the shopping itself. I associate this a little bit with my not knowing how to control money that rarely occurs...

April's comment on whether she was suffering from a disease related to her passion for shopping was also important. It is a preference to dress the way she wants in response to the financial bottleneck she can bear; even a tradeoff in her own words. 


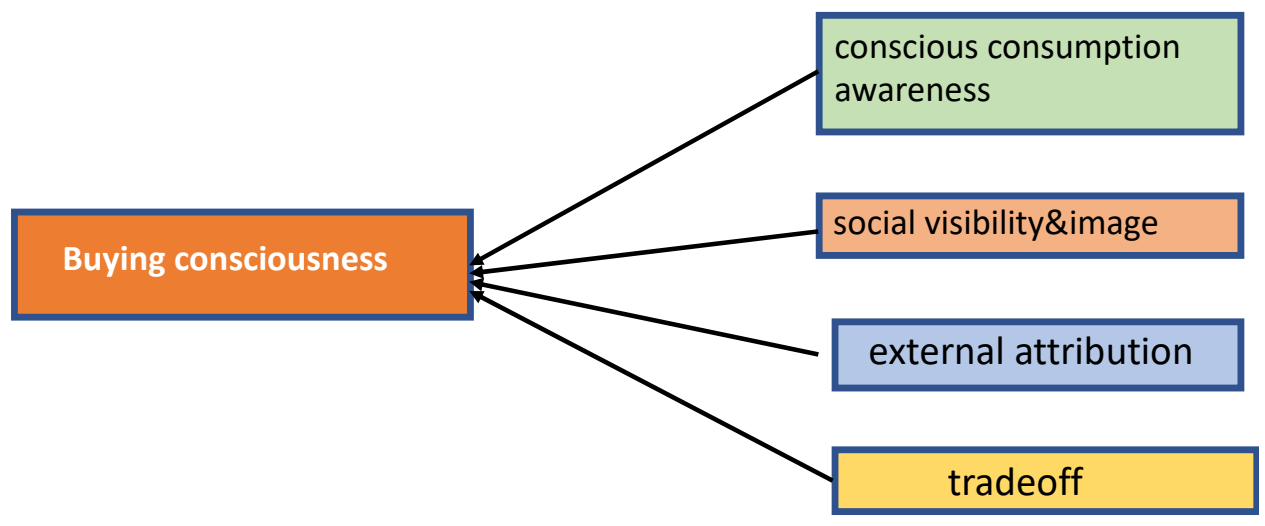

Figure 4: Theme Four and Related Sub-themes

\section{DISCUSSION AND CONCLUSION}

Compulsive buyers are often over-spending and are rarely affected by the price. Moreover, the use of credit cards pushes them to be less conscious about their budgets (Lo \& Harvey, 2011). We see that this research participant also spends high amounts of money from her credit card, even if she is unable to pay.

Compulsive buying has often been associated with depression (Claes et al., 2016; Villardefrancos and Otero-López, 2016; Lawrence et al., 2014). Hirschman (1992) found that while associating compulsive buying behavior with the feeling of inadequacy, individuals display excessive buying behavior as a way of getting away from negative feelings and stress; In this study, the participant also stated that her excessive buying has become a way of dealing with negative feelings and thoughts. She stated that her mood is extremely distinctive in her desire to shop, and when she is depressed, she often tends to shop to feel good.

Various studies show that promotion offering websites represent a particularly attractive shopping context for compulsive buyers due to hedonic and social motivations that affect consumers' response to such contextual factors (Kukar-Kinney et al., 2016). We see that sales promotion practices in both online and physical stores cause this research participant to consume excessively.

There are also studies dealing with the determinants of external factors that push individuals to over-purchase. In this respect, studies conducted based on Self-Determination Theory (Deci and Ryan, 1995) show that the distinction between true self-esteem to contingent self-esteem (CSE) is also determinant in compulsive purchasing and individuals with high CSE focus are focused on providing external standards; It has been demonstrated that they decide their self-worth based on their physical attraction, social position, job performance, or to what extent they meet other evaluation standards (Patrick, Neighbors and Knee, 2004). The same approach has been examined in the role of the distinction between the real self and the ideal self in compulsive buying, and it has been demonstrated in various studies in which compulsive buying is shown to reach the ideal self, which is largely shaped by social interactions (Dittmar, 2005). Compulsive buying, which is closely associated with Festinger's (1954) Social Comparison Theory, is explained by the need to evaluate themselves, individuals' sensitivity to the reactions of others and their tendency to social comparison. Various studies have shown that the individual who focuses on what others think about is also open to their influence (Roberts et al., 2014). In this study, the participant drew attention to social visible factors such as social 
acceptance, approval, image, luxury as driving factors in unnecessary excessive purchase behavior.

When these theories and their implications are evaluated, it is seen that compulsive buying behavior patterns that coincide with the inferences about self-consciousness are revealed. Previously, in Burnkrant and Page (1981), it has been revealed that individuals with high public self-consciousness carry out their consumption behaviors to create favorable impressions. Individuals with high public self-consciousness also need to associate their own behavior with the behavior of others; needs such as social acceptance and awareness that can be met through social interaction; hence socially conspicuous consumption and ownership of products; in a way they are more prone to materialism (Tunnell, 1984; Burnkrant and Page, 1981; Xu, 2008). Indeed, focusing on physical appearance over clothing has been revealed as one of the most important precursors of compulsive buying (Solomon and Schlonker, 1982; Schlenker and Leary, 1982; Harnish et al., 2018).

Since the financial cost of compulsive purchasing is too much to be insignificant, individuals are both consciously and unconsciously disturbed by excessive purchasing behavior (Zhang et al., 2017). Studies show that compulsive buyers are self-controlling but differ from cautious buyers in how they implement self-control measures (Horváth et al., 2015). In this study, the participant's self-assessment of excessive consumption behavior and the effort to control excessive consumption and watching herself with a third eye show that she also has a private self-consciousness. As a matter of fact, changing the conditions and reactions of Baumeister's (2002) it might be inferred that self-regulation (self-control), which Brown (1998) defines as the capacity to plan, direct and monitor one's behavior flexibly in the face of changing conditions, is also an important indicator of private self-consciousness. Therefore, excessive consumption can be interpreted as a desire arising from external, mostly social factors rather than being an uncontrolled consumption behavior away from consciousness.

In this study, another factor that the participant particularly emphasizes and prepares the ground for excessive consumption is shopping as a leisure activity. Baudrillard's (2010) "shopping malls that bring together the scattered functions of social life and togetherness (work, leisure time, nutrition, health, transportation, media, culture) under a single homogeneous roof (time / space)" has become the venue. The fact that the participant said that she generally preferred to buy expensive gifts and exhibit compulsive buying behavior while buying gifts shows that she received gifts with an altruistic motivation as a part of the social exchange and extended self (Belk, 1977; Belk and Coon, 1993).

An important finding revealed in studies on compulsive purchasing is that this type of excessive purchase behavior is more common in women, and it focuses on products such as clothing and cosmetics (Miltenberger et al., 2003; Black, 2007). In this study, the case unit was also a woman, and the findings obtained from her also confirmed the previous research findings. She also expressed her fondness for purchasing clothing and cosmetics.

In general, when all findings are evaluated together, we might infer that both private and public consciousness related factors are effective on excessive consumption behavior, and that self-control can be achieved because of this consciousness.

I can suggest that everyone who exhibits the characteristics of compulsive buyers should be examined in detail before a disease or behavioral disorder is diagnosed and that the motivations driving this behavior should be addressed. As a matter of fact, I saw in the subject of this study that the motivations in excessive consumption behavior intertwined with conspicuous consumption. 
Considering the common critiques related to case study, future research could be designed as multiple cases recruiting more participants from diverse demographics and the role of self under different features.

\section{Declaration of Research and Publication Ethics}

This study has been carried out in accordance with the rules of scientific research and publication ethics. Also, the study has an ethics committee approval from Kutahya Dumlupinar University (18.12.2020/11).

\section{Authors' Contribution}

This study is prepared by a single author.

\section{Declaration of Conflict of Interest}

There is no conflict of interest.

\section{APPENDICES}

\section{Appendix A}

Compulsive Buyer Screener Survey Questions (Online)

-Do you shop when you feel angry or disappointed?

$\begin{array}{ll}\square \text { Yes } & \square \text { No } \\ \square \text { Yes } & \square \text { No } \\ & \\ \square \text { Yes } & \square \text { No } \\ \square \text { Yes } & \square \text { No } \\ \square \text { Yes } & \square \text { No } \\ & \\ \square \text { Yes } & \square \text { No } \\ & \\ \square \text { Yes } & \square \text { No } \\ \square \text { Yes } & \square \text { No }\end{array}$

-Has overspending created problems in your life?

-Do you have conflicts with loved ones about

your need to shop?

-While shopping, do you feel euphoric rushes or anxiety?

-After shopping, do you feel like you have just finished

doing something wild or dangerous?

$\square$ Yes $\square$ No

-After shopping, do you ever feel guilty or embarrassed about what you have done?

-Do you frequently buy things that you

never end up using or wearing?

-Do you think about money almost all the time?

\section{Appendix B}

\section{Semi-Structured Interview Questions}

1. Can you briefly introduce yourself?

2. Can we talk a little bit about your shopping practice? Who does shopping at home? How often? Where from?

3. If we talk about your shopping practice... what is your shopping frequency? Where from? How do you buy?

4. In fact, you described yourself as someone with a high passion for shopping, or even as a shopaholic in our preliminary interview. Can we talk about it a little bit? How often do you shop? What is your motivation (s)?

a. Why do you think you shop a lot?

5. What are you buying? Are they in line with your needs or unplanned purchases?

6. Do you have any regrets after purchasing? Or do you feel guilty?

a. Do you ever say what am I doing / what have I done? Or that you said I lost consciousness when I saw what you bought?

b. Are you someone who questions what you're doing and why? Would you make an effort to make sense of yourself and what you do?

i. Do you think a lot about your shopping experience? Conscious consumption or not? Would you have an effort to justify this purchase in your mind and against others? Would you make an effort to make sense of yourself and your shopping experience? Or would you not think about it at all?

c. Would you criticize yourself on this or other issues? Do you think you are cruel to yourself?

7. What is the range of your shopping amounts? What is your payment option? (Can I learn your card limit, if any?)

a. What is your monthly statement amount? How much of this is due to your unplanned purchases?

b. Do you make your card payments regularly? Do you have any difficulties economically? How do you solve it?

8. If we talk about the products, you bought... what do you buy? Do you focus on a certain product group? 
a. To what extent can you say products about how you look at others?

i. Do you care about your appearance?

ii. Do you care what others think of you?

iii. Are you worried about making a good impression on people?

iv. How would you relate all of these to your shopping experiences?

b. Could you say that I can explain what you do and why, in terms of your shopping experiences?

9. Have you tried to make an individual change in your passion for shopping or think you need professional support?

Have you done any research on this topic? What, what kind of efforts have you made?

\section{Appendix C}

\section{Audit Trail}

July 2020 Conferring on the relevant research idea and design with the colleagues

July-September 2020 Literature review on compulsive buying and case study method

October 20, 2020 Participant selection through compulsive buyer screener (via online survey)

October 25, 2020 Met the participant face to face to inform her of the study in detail and obtained the informed consent form for each data source (interview, document and observation)

November 1, 2020 Carried out the face-to-face interview (semi-structured) (main)

November 2-5, 2020 Transcribed and analyzed the data

November 15, 2020 Accompanied April to her shopping mall visit and make observation

November 28, 2020 Carried out phone call (unstructured) interview at the time of Black Friday Sale

December 1, 2020 Accompanied April to her shopping mall visit and make observation

December 4, 2020 Carried out phone call (unstructured) interview after Black Friday Sale

December 5, 2020 Visited April at home and took photos of her room, clothing and the like

December 15, 2020 Accompanied April to her shopping mall visit and make observation

December 23, 2020 Evaluated store loyalty upon subscription through mobile apps and mail list

December 25, 2020 Accompanied April to her shopping mall visit at the time of Christmas and New Year shopping and make observation

December 26, 2020 Carried out phone call (unstructured) interview at the time of Christmas Sale

January 1, 2021 Carried out phone call (unstructured) interview after Christmas Sale

January 1-15, 2021 Transcribed and analyzed the two interviews (Christmas Sale) data call interviews

January 15-17, 2021 Member checking with April to review the transcribed data

January 18-23, 2021 Data analysis through transcribed interviews and observations

January 23-February 3, 2021 Collaborated with the expert colleagues and asked their confirmation on the categories and themes I developed 


\section{REFERENCES}

Bailey, K.D. (1982) Methods of social research. Free Press, New York.

Bas, Y. (2016). The dimensions of consumers' shopaholic behaviors and scale development. Journal of Management, Marketing and Logistics, 3(1), 64-86.

Baškarada, S. (2014). Qualitative case study guidelines. The Qualitative Report, 19(40), 1-18.

Baudrillard, J. 2010. Simülakrlar ve simülasyon. (Translated by O. Adanır, designed by T. Takış) Ankara: Doğu Batı Yayınları

Baumeister, R. F. (2002). Yielding to temptation: Self-control failure, impulsive purchasing, and consumer behavior. Journal of Consumer Research, 28, 670-676.

Baxter, P., \& Jack, S. (2008). Qualitative case study methodology: Study design and implementation for novice researchers. The Qualitative Report, 13(4), 544-559.

Belk, R W. (1973). Application and analysis of the behavioural differential inventory for assessing situational effects in consumer behaviour. In Ward S. and Wright. K. (eds.), Advances in Consumer Research., 370-380, Ann Arbor, Michigan: Association for Consumer Research.

Belk, R. W. (1977). Gift-giving behavior. Faculty Working Papers. University of Illinois at Urbana-Champaign.

Belk, R. W. (1988). Possessions and the extended self. Journal of Consumer Research, 15(2), 139-168.

Belk, R. W., \& Coon, G. S. (1993). Gift giving as agapic love: An alternative to the exchange paradigm based on dating experiences. Journal of Consumer Research, 20(December), 393-417.

Bighiu, G., Manolic, A., \& Roman, C.T. (2015). Compulsive buying behavior on the internet. Procedia Economics and Finance. 7th International Conference on Globalization and Higher Education in Economics and Business Administration, GEBA 201320 (2015) 72 - 79.

Black, D.W. (2007). A review of compulsive buying disorder. World Psychiatric Association (WPA), 6(1), 14-18.

Brown, J. M. (1998). Self-regulation and the addictive behaviors. In W. R. Miller, \& N. Heather (Eds.), Treating addictive behaviors (2nd ed., pp. 61-73). New York, NY: Plenum Press.

Burnkrant, R. E., \& Page, T. J. (1981). On the management of self-images in social situations: the role of public selfconsciousness, in Mitchell, A. (Ed.), Advances in Consumer Research, Vol. 9, Association for Consumer Research, Ann Arbor, MI, 452-455.

Bushman, B. J. (1993). What's in a name? The moderating role of public self-consciousness on the rela- tion between brand label and brand preference. Journal of Applied Psychology, 78, 857-861.

Chaker, A. M. (2003). Hello, I'm a shopaholic! There's a move afoot to make compulsive shopping a diagnosable mental disorder: But should it be? Wall Street Journal (January 14), F-1.

Claes, L., Müller, A., \& Luyckx, K. (2016). Compulsive buying and hoarding as identity substitutes: The role of materialistic value endorsement and depression. Comprehensive Psychiatry, 68 (2016) 65-71.

Creswell, J. W. (2009). Research design: Qualitative, quantitative, and mixed methods approaches (3rd ed.). Thousand Oaks, CA: Sage.

Deci, E. L., \& Ryan, R. M. (1995). Human autonomy: The basis for true self-esteem. In M. H. Kemis (Ed.), Efficacy, agency, and self-esteem (pp. 31-49). New York: Plenum.

Denzin, N. K., \& Lincoln, Y. S., (2005). The sage handbook of qualitative research (3rd ed.). Thousand Oaks, CA: Sage.

Desarbo, W. S. \& Eliabeth E. (1996). Typologies of compulsive buying behavior: a constrained clusterwise regression approach. Journal of Consumer Psychology, 5(3),231-262.

Dittmar H. (2005). A new look at compulsive buying: self-discrepancies and materialistic values as predictors of compulsive buying tendency. Journal of Social Clinical Psychology, 24(6), 832-859.

Dittmar, H., \& Drury, J. (2000). Self-image - Is it in the bag? A qualitative comparison between "ordinary" and "excessive" consumers. Journal of Economic Psychology, 21, 109-142.

Faber, R.J., \& O'Guinn, T.C. (1992). A Clinical Screener for Compulsive Buying. Journal of Consumer Research, 19(3),459-469. 
Faber, R.J., Christenson, G.A., de Zwaan, M. \& Mitchell, J. (1995). Two Forms of Compulsive Consumption: Comorbidity of Compulsive Buying and BingeEating. Journal of Consumer Research, 22(3),296-304

Fenigstein, A., Scheier, M.F., \& Buss, A.H. (1975). Public and private self-consciousness: assessment and theory. Journal of Consulting and Clinical Psychology, 43(4), 522-527.

Festinger, L. (1954). A Theory of social comparison process. Human Relations, 7, 117-140.

Flyvbjerg, B. (2006). Five misunderstandings about case-study research. Qualitative Inquiry, 12(2), 219-245.

Granero, R., Fernandez-Aranda, F., \&... Jiménez-Murcia, S. (2016). Compulsive Buying Behavior: Characteristics of Comorbidity with Gambling Disorder. Frontiers in Psychology, 7(957), 1-10.

Harnish, R. J., Gump, J. T., Bridges, K. R., Slack, F. J. \& Rottschaefer, K. M. (2018). Compulsive buying: The impact of attitudes toward body image, eating disorders, and physical appearance investment. Psychological Reports, 122(5), $1632-1650$

Harvanko, A., Lust, K., Odlaug, B. L., .........Grant, J. E. (2013). Prevalence and characteristics of compulsive buying in college students. Psychiatry Research, 210(2013), 1079-1085.

Hirschman, E.C. (1992). The consciousness of addiction: Toward a general theory of compulsive consumption. Journal of Consumer Research, 19(2), 155-179

Horváth, C., Büttner, O.B., Belei, N., \& Adigüzel, F. (2015). Balancing the balance: Self-control mechanisms and compulsive buying. Journal of Economic Psychology, 49(2015), 120-132.

Kearney M, Stevens L. (2012). Compulsive buying: Literature review and suggestions for future research. The Marketing Review 12 (3), 233-251.

Konkolÿ, Thege, B., Woodin, E. M., Hodgins, D. C., \& Williams, R.J. (2015). Natural course of behavioral addictions: A 5-year longitudinal study. BMC Psychiatry 15(4).

Koran, L.M., Faber, R.J., Aboujaoude, E., D. Large, M., \& Serpe, R.T. (2006). Estimated Prevalence of Compulsive Buying Behavior in the United States. American Journal of Psychiatry, 163(10), 1806-1812

Krueger DW. (1988). On compulsive shopping and spending: a psychodynamic inquiry. American Journal of Psychotherapy, 42(4), 574-584.

Kukar-Kinney, M., Scheinbaum, A. C., \& Schaefers, T. (2016). Compulsive buying in online daily deal settings: An investigation of motivations and contextual elements. Journal of Business Research, 69(2), 691-699.

Kwon, Y-H. (1992). Body consciousness, self-consciousness, and women's attitudes toward clothing practices. Social Behavior and Personality: An International Journal, 20, 295-307.

Lawrence, L.M., Ciorciari, J., \& Kyrios, M. (2014). Relationships that compulsive buying has with addiction, obsessive-compulsiveness, hoarding, and depression. Comprehensive Psychiatry, 55 (2014), 1137-1145

Lejoyeux M, Ades J, Tassain V.... (1996). Phenomenology and psychopathology of uncontrolled buying. American Journal of Psychiatry, 153, 1524-1529.

Lejoyeux, M., \& Weinstein, A. (2010). Compulsive Buying. The American Journal of Drug and Alcohol Abuse, Early Online, $1-6$.

Levy, S. (1959). Symbols for sale. Harvard Business Review, (July/August), 117-124.

Lo, Hui-Yi \& Harvey, N. (2011). Shopping without pain: Compulsive buying and the effects of credit card availability in Europe and the Far East. Journal of Economic Psychology, 32(2011), 79-92.

Marquis, M., \& Filiatrault, P. (2000). Cognitive and affective reactions when facing an additional delay while waiting in line: A matter of self-consciousness disposition. Social Behavior and Personality, 28(4), 355-276.

Merriam, S. B. (1998). Qualitative research and case study applications in education. San Francisco, CA: JosseyBass.

Miles, M. B., \& Huberman, A. M. (1994). Qualitative data analysis: An expanded sourcebook. Thousand Oaks, CA: Sage.

Miltenberger, R.G., Redlin, J., Crosby, R., Stickney, M., Mitchell, J., Wonderlich, S., Faber, R., \& Smyth, J. (2003). Direct and retrospective assessment of factors contributing to compulsive buying. Journal of Behavior Therapy and Experimental Psychiatry, 34(1), 1-9.

Morse, A., \& McEvoy, C.D. (2014). Qualitative research in sport management: Case study as a methodological approach. The Qualitative Report, 19, How to Article 17, 1-13. 
Mueller, A., Mitchell, J.E., Peterson, L.A., \&......Claes, L. (2011). Depression, materialism, and excessive Internet use in relation to compulsive buying. Comprehensive Psychiatry, 52 (2011) 420-424.

Müller, A., Mitchell, J.E., \& deZwaan, M. (2015). Compulsive Buying. American Journal of Addiction, 24, 132-137.

Park, Hye-Jung, \& Burns, L.D. (2005). Fashion orientation, credit card use, and compulsive buying. Journal of Consumer Marketing, 22(3),135-141.

Patrick, H., Neighbors, C., \& Knee, C. R. (2004). Appearancerelated social comparisons: The role of contingent selfesteem and self-perceptions of attractiveness. Personality and Social Psychology Bulletin, 30, 501-514.

Patton, Q. M. (1987). How to use qualitative methods in evaluation. Newsbury Park, London, New Dehli Sage Publications.

Pirog, S. F., \& Roberts, J. A. (2007). Personality and credit card misuse among college students: The mediating role of impulsiveness. Journal of Marketing Theory and Practice, 15 (1), 65-77.

Ridgway N. M, Kukar-Kinney M, \& Monroe K. M. (2008). An Expanded Conceptualization and New Measure of Compulsive Buying Journal of Consumer Research, 35 (4), 622-639 74

Ridgway, N. M., Kukar-Kinney, M., \& Monroe, K. B. (2008). An Expanded Conceptualization and a New Measure of Compulsive Buying. Journal of Consumer Research, 35(4), 622-639.

Roberts, J. A., Manolis, C., \& Pullig, C. (2014). Contingent self-esteem, self-presentational concerns, and compulsive buying. Psychology and Marketing, 31(2), 147-160.

Roberts, J. A., Manolis, C., \& Pullig, C. (2014). Contingent self-esteem, self-presentational concerns, and compulsive buying. Psychology and Marketing, 31,147-160.

Scheier, M. F. (1980). Effects of public and private selfconsciousness on the public expression of personal beliefs. Journal of Personality and Social Psychology, 39, 514-521

Scheier, M. F., \& Carver, C. S. (1985). The Self-Consciousness Scale: A revised version for use with general populations. Journal of Applied Social Psychology, 15(8), 687-699.

Scherhorn G, Reisch LA, \& Raab G. (1990). Addictive buying in West Germany: An empirical study. Journal of Consumer Policy, 13, 355-387.

Schlenker, B. R., \& Leary, M. R. (1982). Social anxiety and selfpresentation: A conceptualization model. Psychological Bulletin, 92(3), 641-669.

Solomon, M. R., \& Schopler, J. (1982). Self-consciousness and clothing. Personality and Social Psychology Bulletin, $8,508-514$.

Stake, R. E. (1995). The art of case study research. Thousand Oaks, CA: Sage.

Starman, A.B. (2013). The case study as a type of qualitative research. Journal of Contemporary Educational Studies, $1 / 2013,28-43$.

Strauss, A. \& Corbin, J. (1998). Basics of qualitative research: Techniques and procedures for developing grounded theory (2nd ed.). Thousand Oaks, CA: Sage.

Tellis, W. M. (1997). Introduction to case study. The Qualitative Report, 3(2), 1-14.

Thomas, G. (2011). A Typology for the case study in social science following a review of definition, discourse and structure. Qualitative Inquiry, 17(6), 511-521.

Tunnell, G. (1984). The discrepancy between private and public selves: public self-consciousness and its correlates. Journal of Personality Assessment, 48(5), 549-555.

Valence, G., d'Astous, A., \&Fortier, L. (1988). Compulsive buying: Concept and measurement. Journal of Consumer Policy, 11 (1988), 419-433.

Villardefranco, E., \& Otero-López, J.M. (2016). Compulsive buying in university students: its prevalence and relationships with materialism, psychological distress symptoms, and subjective well-being. Comprehensive Psychiatry, 65 (2016), 128-135.

Vissak, T. (2010). Recommendations for using the case study method in international business research. The Qualitative Report, 15(2), 370-388.

Vitor, D. A., Ayimey, E. K. \& Gayibor, R. A. (2013). Impact Of Sales Promotion Techniques on Impulse Buying Behavior. Asian Journal Management. 
Vogt, S., Hunger, A., Türpe, T., Pietrowsky, R., \& Gerlach, A. L. (2014). Effects of mood induction on consumers with vs. without compulsive buying propensity: An experimental study. Psychiatry Research, 220(1-2), 342-347.

Winestine M. C. (1985). Compulsive shopping as a derivative of childhood seduction. The Psychoanalytic Quarterly, 54(1), 70-72.

Yin, R. K. (2003). Applications of case study research (2nd ed.). Thousand Oaks, CA: Sage.

Yin, R. K. (2009). Case study research: Design and methods (4 ed.). Los Angeles, CA: Sage.

Yingjiao X. (2008). The influence of public self-consciousness and materialism on young consumers' compulsive buying. Young Consumers, 9(1), 37-48,

Zhang, C., Brook, J. S., Leukefeld, C. G., De La Rosa, M., \& Brook, D. W. (2017). Compulsive buying and quality of life: An estimate of the monetary cost of compulsive buying among adults in early midlife. Psychiatry Research, 252(2017), 208-214.

https://www.psychguides.com/behavioral-disorders/shopping-addiction/ 